\section{An Expert System for Integrated Production Management in Muskmelon}

\author{
Glenn H. Sullivan', William J. Ooms ${ }^{2}$, and Gerald E. Wilcox ${ }^{3}$ \\ Department of Horticulture, Purdue University, West Lafayette, IN 47907
}

\author{
Douglas C. Sanders ${ }^{4}$ \\ Department of Horticultural Sciences, North Carolina State University, \\ Raleigh, NC 27695-7609
}

Additional index words. management expert systems, artificial intelligence, vegetable production, decision support systems

Abstract. A management expert system that enables producers to fully assess the integrated resource requirements, management risks, and profit potential for growing muskmelon was developed. The expert system environment Guru was used as the development software.

Competition in the production of vegetable crops has intensified as more domestic producers seek to diversify their overall farm income. A critical need exists for management decision support systems that enable producers to allocate economic resources so that they will minimize economic risk and maximize net return to management in competitive markets. The cultural practices for horticultural crops are more complex than for most agronomic crops and different for each growing region. Successful production involves many integrated management decisions, including production scheduling, resource management, variety selection, fertilizer application, pest management, irrigation scheduling, and economic analysis (Sullivan and Ooms, 1990; Wilcox et al., $1988,1989)$, all of which require access to accurate database and reasoning knowledge.

Computer-based management programs offer perhaps the greatest opportunity for assuring that integrated management decision support systems will be available commensurate with the future needs of producers (Bonczek et al., 1981; Holt, 1989; Sullivan and Ooms, 1990; Sullivan et al., 1989). Although management software programs have proliferated, acceptance and application among agricultural producers has been very limited. To facilitate acceptance, management decision support systems must be fully

\footnotetext{
Received for publication 9 Oct. 1990. Accepted for publication 16 Dec. 1991. Purdue Univ. Agricultural Experiment Station Journal no. 12645 The cost of publishing this paper was defrayed in part by the payment of page charges. Under postal regulations, this paper therefore must be hereby marked advertisementsolely to indicate this fact. ${ }^{1}$ Professor, Marketing Economics.

${ }^{2}$ Systems Engineering Economist.

${ }^{3}$ Professor, Plant Nutrition.

${ }^{4}$ Professor, Horticulture.
}

integrated, have multiple problem-solving capabilities, be interactive and very userfriendly, and provide a dynamic planning environment for strategic and tactical production decisions (Holsapple and Whinston, 1987; Sullivan et al., 1989).

Management expert systems provide producers with a new generation of integrated computer technology for achieving the levels of management efficiency needed to compete in a market-driven economy (Sullivan et al., 1989). This research focused on the development of a highly interactive management expert system (MES), using an expert system environment as the development software, that enables producers to fully assess the integrated resource requirements, management risks, and profit potential for the strategic and tactical decisions in muskmelon production.
$M E S$. Advances in artificial intelligence technology and expert system knowledge engineering have created opportunities for the development and commercial implementation of a new generation of computer applications in the management of production enterprises (Holsapple and Whinston, 1987; Holt, 1989; Sullivan et al., 1989). Expert systems incorporate artificial intelligence to solve problems in a manner that emulates human experts (Andriole, 1985). MESS, which represent a relatively new development in the field of artificial intelligence, offer highly integrated analytical and reasoning capabilities in problem-solving and can be implemented in a broad range of production management situations (Sullivan et al., 1988, 1989).

MESS synergistically integrate traditional business computing capabilities, such as spreadsheet analysis and database management, with the artifical intelligence technology of natural language processing and inference into a dynamic problem-solving program to significantly enhance the innate performance capability of the user (Fig. 1). Therefore, knowledge-based agriculture management programs can be developed to evaluate all the production variables involved in selecting, growing, and marketing crops for an overall farming situation and to solve specific production problems that arise during the growing season. This capability enables users at all levels of expertise to make direct inquiries on production management problems as decisions need to be made (Sullivan et al., 1989).

MES for muskmelon production. Research in the Horticulture Dept., Purdue Univ., has focused on the development of MES for production management and decision support in vegetable crops. The first applications, using the expert system shell PC Plus, were developed and tested in the field in 1988 (J.C.

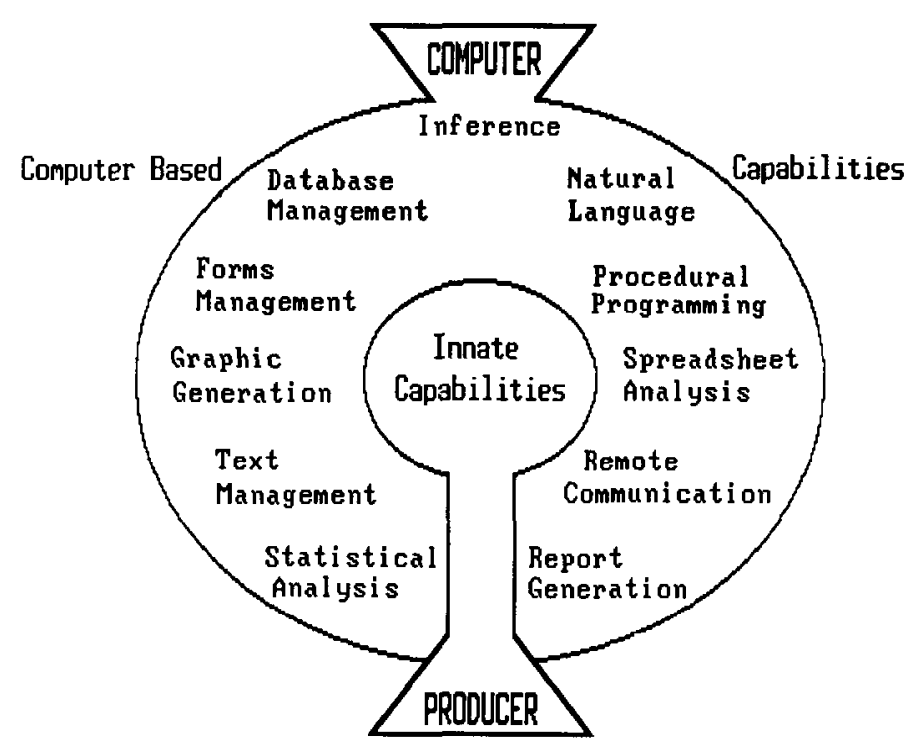

Fig. 1. Performance capabilities of a synergistically integrated management expert system. 


\begin{tabular}{|c|c|c|c|c|}
\hline Database Information & Strategic Decision Frame & \multicolumn{3}{|c|}{ Tactical Decision Frames } \\
\hline Bnowloghe & \multicolumn{4}{|c|}{ ঝ/. } \\
\hline Primary Databases & & Production Schedule & Resource Mgt. & Varlety Selection \\
\hline \multirow[t]{2}{*}{$\begin{array}{l}\text { Farmer's Resources } \\
\text { Land } \\
\text { Field Size } \\
\text { Soil Type } \\
\text { Machinery } \\
\text { Labor Available } \\
\text { History of Farm } \\
\text { Chemicals Used } \\
\text { Crop History } \\
\text { Irrigation } \\
\text { Farm's Daily Weather } \\
\text { Rainfall } \\
\text { Temperature } \\
\text { Economic Budget } \\
\text { Prices Received } \\
\text { Fixed Costs } \\
\text { Variable Costs }\end{array}$} & \begin{tabular}{l}
\multicolumn{1}{c}{ Plant } \\
Recommendation \\
MES recommends that \\
producing muskmelon \\
may be profitable.
\end{tabular} & $\begin{array}{l}\text { Provides expert } \\
\text { recommendations on } \\
\text { scheduling all cultural } \\
\text { practices. Determines } \\
\text { strategic planting } \\
\text { schedule based on } \\
\text { climatic conditions } \\
\text { and crop requirements, } \\
\text { fitted with optimum } \\
\text { marketing. }\end{array}$ & $\begin{array}{l}\text { Calculates the specific } \\
\text { needs, availability, } \\
\text { and costs of land, } \\
\text { machinery, labor and } \\
\text { other resources } \\
\text { required for musk- } \\
\text { melon production on } \\
\text { producers designated } \\
\text { fields and provides a } \\
\text { detailed utilization } \\
\text { schedule. }\end{array}$ & $\begin{array}{l}\text { Provides rexpert } \\
\text { recommendations on } \\
\text { muskmelon varieties } \\
\text { for prodifiers' } \\
\text { specified conditions, } \\
\text { including disease } \\
\text { resistance, fruit size, } \\
\text { plant maturity } \\
\text { schedules and market } \\
\text { quality. }\end{array}$ \\
\hline & Plant/No Plant & Cultural Practices & Fertilizer Mgt. & Pest Management \\
\hline & \multirow{3}{*}{$\begin{array}{l}\text { Assimilates knowl- } \\
\text { edge relating to the } \\
\text { producers' resources, } \\
\text { market altematives, } \\
\text { growing experience, } \\
\text { field history, soil type } \\
\text { and management } \\
\text { capacity and provides } \\
\text { an expert recommen- } \\
\text { dation to plant; or not } \\
\text { to plant if critical } \\
\text { parameters are not met } \\
\text { with acceptable levels } \\
\text { of certainty. }\end{array}$} & \multirow[t]{3}{*}{$\begin{array}{l}\text { Provides expert } \\
\text { recommendations to } \\
\text { optimize all caltural } \\
\text { practices and proc. } \\
\text { esses involved in } \\
\text { muskmelon produc- } \\
\text { tion including: field } \\
\text { preparation, mulching. } \\
\text { row covers, planting } \\
\text { and transplanting, and } \\
\text { harvesting procedures. }\end{array}$} & \multirow{3}{*}{$\begin{array}{l}\text { Provides expert } \\
\text { recommendations for } \\
\text { fenilizer and lime } \\
\text { application rates based } \\
\text { on each field's soil } \\
\text { type, soil test results } \\
\text { and muskmelon } \\
\text { requirements. Also } \\
\text { recommends the } \\
\text { method of application } \\
\text { and source of fertilizer } \\
\text { materials including } \\
\text { nitrogen, phosphorus, } \\
\text { potassium, lime and } \\
\text { pH levels, and various } \\
\text { micronutrients. }\end{array}$} & \multirow{3}{*}{$\begin{array}{l}\text { Provides the producer } \\
\text { with expert recom- } \\
\text { mendations on the } \\
\text { control of weeds, } \\
\text { insects and diseases } \\
\text { common to musk- } \\
\text { melon. Assists the } \\
\text { producer in selecting } \\
\text { herbicides, insecti- } \\
\text { cides and fungicides } \\
\text { for specific pest } \\
\text { control, snd provides } \\
\text { recommended applica- } \\
\text { tion rates and } \\
\text { schedules. }\end{array}$} \\
\hline Secondary Databases & & & & \\
\hline $\begin{array}{l}\text { Crop Requirements } \\
\text { Labor Required } \\
\text { Growing Season } \\
\text { Marketing Options }\end{array}$ & & & & \\
\hline \multirow{3}{*}{$\begin{array}{l}\text { Regions Weather Data } \\
\text { Temperature } \\
\text { Rainfall } \\
\text { Evapotranspiration } \\
\text { Pesticide Information } \\
\text { Chemical Name } \\
\text { Application Rates } \\
\text { Pests Controlled }\end{array}$} & & Irrigatlon Schedule & Economic Analysis & User Interface \\
\hline & & \multirow{4}{*}{$\begin{array}{l}\text { Optinizes irrigation } \\
\text { applications by pro- } \\
\text { viding expen sched- } \\
\text { uling recommenda- } \\
\text { tions based on } \\
\text { muskmelon require- } \\
\text { ments, soil character- } \\
\text { istics, water gained } \\
\text { through rainfall and } \\
\text { irrigation, and loss } \\
\text { through evaporation } \\
\text { and transpiration. The } \\
\text { irrigation schedule } \\
\text { provides optimum } \\
\text { water availability for } \\
\text { plant growth and } \\
\text { development. }\end{array}$} & \multirow{4}{*}{$\begin{array}{l}\text { Assimilates producer } \\
\text { resource and input } \\
\text { costs including fertil- } \\
\text { izer, pesticide, fumi- } \\
\text { gation. irrigation. } \\
\text { interest or operating } \\
\text { capital, machinery and } \\
\text { equipment, land rent, } \\
\text { preharvest labor and } \\
\text { harvest labor costs. } \\
\text { Economic retums to } \\
\text { management are deter- } \\
\text { mined and provided } \\
\text { on a per acre basis } \\
\text { after gross revenues } \\
\text { gre input by the } \\
\text { producer. }\end{array}$} & 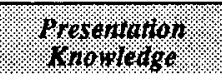 \\
\hline & $\begin{array}{l}\text { Do NOT Plant } \\
\text { Recommendation }\end{array}$ & & & Input Forms \\
\hline $\begin{array}{l}\text { Soil Texture } \\
\text { Water Holding } \\
\text { Capacity } \\
\text { Water Intake Rate }\end{array}$ & $\begin{array}{l}\text { MES recommends not } \\
\text { to produce musk- } \\
\text { melon, and gives } \\
\text { reasons why. }\end{array}$ & & & $\begin{array}{l}\text { Report Layouts } \\
\text { Natural Language } \\
\text { Vocabularies }\end{array}$ \\
\hline $\begin{array}{l}\frac{\text { Economic }}{\text { Startup Costs }} \\
\text { Machinery } \\
\text { Expected Price \& } \\
\text { Yield }\end{array}$ & & & & $\begin{array}{l}\text { Menu Selections } \\
\text { Data Verification }\end{array}$ \\
\hline
\end{tabular}

๑ Copyrighted 1989. Purdue Research Foundation.

G.H. Sullivan; W.J. Ooms; and G.E. Wilcox, Department of Horticulture, Purdue Univ., West Lafayette, IN 47907.

Fig. 2. Structure of Purdue Univ.'s management expert system for muskmelon.

Rettinger, unpublished; Sullivan et al., 1988). Since then, expert system environments have been used as the development software to achieve fully integrated MES in horticultural crop production (Ooms et al., 1990, Sullivan et al., 1989, 1990). The expert system environment Guru was used to develop the MES for solving integrated problems in muskmelon production (Micro Data Base Systems, 1985). The structure of the muskmelon MES was developed using three distinct subsystems. The language subsystem, problem processing subsystem, and the knowledge subsystem integrate all aspects needed for management decision-making into one software development package (Holsapple and Whinston, 1987; Sullivan et al., 1989).

The MES for muskmelons is comprised of nine integrated production decision frames, including one strategic and eight tactical (Fig. 2). The strategic decision frame permits agricultural development personnel to determine the feasibility for growing muskmelons at a particular site, given available land, labor, equipment, environmental, economic, and management resources. The tactical decision frames assist the producer in making daily production decisions and solving production-related management problems, including: crop scheduling, variety selection, fertilizer management, insect and disease control, irrigation scheduling, and budgeting. Production knowledge can be represented as descriptive, procedural, reasoning, and presentation knowledge (Sullivan et al., 1989). These distinctive types of production management knowledge were incorporated into the Guru development software for en- gineering the knowledge-based MES for muskmelon production.

Descriptive knowledge of the problem domain. Descriptive knowledge included information and facts about the situation in which muskmelon production decisions are made. A knowledge-based program cannot provide reliable advice without accurate and current information, including weather data, crop requirements, soil characteristics, and other production information. The muskmelon MES enables the decision maker to store, maintain, and retrieve masses of accurate and current descriptive knowledge as an important resource for making decisions (Fig. 2).

Procedural knowledge to accomplish a task. Methods or steps taken to accomplish specific production tasks were programmed 
as procedural knowledge. Most production management activities involve a series of interrelated procedures to arrive at a given solution or recommendation, such as budget calculations, resource estimations, application rates, degree-day requirements, and target harvest dates. The muskmelon MES uses this procedural knowledge to perform the function of analyzing the current production situation, including data-based descriptive knowledge, to arrive at a solution and answer specific production-related questions (Fig. 2)

Reasoning knowledge of the expert. The rules of thumb an expert uses to reach a production management decision were programmed as reasoning knowledge. These judgments, such as an expert's reasoning processes for diagnosing insect and disease problems, are critical elements in providing agricultural producers with the integrated management and problem-solving capabilities essential to success. For example, a grower may not know what is causing leaf discoloration in his muskmelon plants. To solve the problem he must apply reasoning and judgment to analyze the identifiable symptoms, diagnose the cause, and arrive at a recommended solution. The muskmelon MES applies expert reasoning to the descriptive and procedural knowledge, similar to human reasoning, in deriving problem solutions and recommendations (Fig. 2). This expert reasoning is the essence of artificial intelligence technology that differentiates expert systems from traditional computer programs.

Presentation knowledge for the user. The technique used to display the results for the user of the MES was programmed as presentation knowledge. This highly interactive program is readily usable in agricultural production enterprises because it interacts with the user in an intuitive manner during the software consultation. The display includes reports, graphs, illustrations, spreadsheets, and natural language to address user inquiries (Fig. 2).

The muskmelon MES provides producers with a new generation of highly user-friendly computer technology to achieve the levels of management efficiency needed to succeed in a competitive economy. It provides unprecedented opportunities for synergistically integrated, highly interactive, and dynamic production management applications (Fig. 2). Control over the user interface creates applications that are easy to use for the inexperienced computer operator while maintaining the sophistication needed to accomplish complicated tasks for those experienced (Fig. 1). With the muskmelon MES, knowledge can be represented in an unstructured manner, thereby providing greater flexibility and utility in making decisions. Multiple problem-solving capabilities in the muskmelon MES program create a management support system with greater breadth and depth than is possible with structured computer programs, or with expert system shells alone, thus producing a synergistic integration of the components in decision-making that generates a more useful result than the sum of the individual decision frames.

The need for expert information on a constant and reliable basis will continue to be increasingly critical to the competitiveness and economic success of producers. MESS effectively provide the necessary support. A knowledge-based production MES, such as the one for muskmelon, provides producers with the opportunity to increase their overall management expertise to the highest level attainable, regardless of the producer's current level of knowledge. Production MESS provide significant new opportunities to enhance the productivity of producers while strengthening the information support sys- tems on which future crop management decisions are made.

\section{Literature Cited}

Andriole, S.J. 1985. Applications in artificial intelligence. Petrocelli Books, Princeton, N.J.

Bonczek, R. W., C.W. Holsapple, and A.B. Whinston. 1981. Foundations of decision support systems. Academic, New York.

Holsapple, C.W. and A.B. Whinston. 1987. Business expert systems. Irwin, Homeward, 111.

Holt, D.A. 1989. The growing potential of expert systems in agriculture, p. 1-11. In: D.J. Jones and J. Barrett (eds.). Knowledge engineering in agriculture. Amer. Sot. Agr. Eng., St. Joseph, Mich.

Micro Data Base Systems. 1985. Guru reference manuals. vol. 1-2. Lafayette, Ind

Ooms, W.J., G.H. Sullivan, and G.E. Wilcox. 1990. Expert system environments for integrated production management decision making. J. Computers \& Electronics in Agr. Purdue Univ. Agr. Expt. Sta. 12507.

Sullivan, G.H. and W.J. Ooms. 1990. Knowledge-based extension management programs using expert system environments. Proc. 3rd Intl. Conf. Computers in Agr. Ext. Programs, Lake Buena Vista, Fla., Jan. 1990. p. 367-372.

Sullivan, G. H., W.J. Ooms, and G.E. Wilcox. 1990. Knowledge-based production management programs for agricultural development. Proc. 3rd Intl. Sym. Aritifical Intelligence, Monterrey, Mexico. Purdue Univ. Agr. Expt. Sta. 12406.

Sullivan, G. H., W.J. Ooms, and G.E. Wilcox. 1989. Expert systems: Advanced artificial intelligence concepts for integrated crop management. HortScience 24:739-742.

Sullivan, G. H., W.J. Ooms, and G.E. Wilcox. 1988. User's guide: Expert system for muskmelon production management. Purdue Univ. Agr. Expt. Sta. Res. Bul. 987.

Wilcox, G. E., W.J. Ooms, and G.H. Sullivan. 1988. Expert system schedules profitable muskmelon. Amer. Veg. Grower 36(12):51-52.

Wilcox, G. E., G.H. Sullivan, and W.J. Ooms. 1989. Expert system enhances irrigation. Amer. Veg. Grower 37(2):62-65. 